\title{
DESCRIPTION OF A NEW FOSSIL FERN OF THE GENUS GLEICHENIA FROM THE UPPER CRETACEOUS OF WYOMING.
}

\author{
By Frank H. Knowlton. \\ Custodian of Mesozoic plants, United States National Museum.
}

The family Gleicheniaceæ is undoubtedly a very old one, though there is perhaps still reasonable doubt as to its being quite so ancient as it was at one time believed to be. The genus Gleichenites, so named on account of its supposed affinity to the living family, was instituted by Göppert ${ }^{1}$ for certain fronds from the Carboniferous of Silesia, but this group was evidently composite and the several species have been allocated in Neuropteris, Sphenopteris, Eremopteris, etc., some or all of which are now known to be included in the Pteridosperms. A number of other Carboniferous fronds, such as Mariopteris Zeiller, Diplothmema Stur, etc., on account of their regular, dichotomous, gleichenoid habit of branching, have a more or less strong resemblance to the living Gleicheniaceæ, but both these forms are now placed in the Pteridosperms, and the dichotomous branching can not be regarded as establishing affinity to the living family. Much more important in this connection are specimens showing the arrangement and character of the fruiting organs, but even when these are present great caution is necessary since the accidents of preservation may render a correct interpretation difficult, if not impossible. Thus, Williamson ${ }^{2}$ figured from the English Coal Measures a specimen which he regarded as the "sporangium of a fern allied to the Gleicheniaceæ or Schizaeaceæ," which certainly appears to possess a complete annulus, but this has been interpreted by later authors as a mistaken observation on an exannulate Marattiaceous sporangium. A much better case appears to be made out for the fruit of Oligocarpia of Göppert (especially $O$. brongniarti Stur), these being small ferns with Sphenopteroid foliage bearing circular sori made up of from 6 to 10 pyriform sporangia. Zeiller ${ }^{3}$ in particular has claimed that they show a complete transverse annulus, and though this has been ques-

1 Syst. Fil. Foss., 1836, p. 181.

2 Philos. Trans., vol. 167, pt. 1, 1877, pl. 7, figs. 27, 28.

3 Bassin Houiller du Valenciennes, Flore fossile, 1888, p. 53 et seq.

Proceedings U. S. National Museum, Vol. 45-No. 1994. 
tioned by Stur, Solms-Laubach, Schenk, and others, Scott, ${ }^{1}$ who has seen some of the material, inclines to give it credence. He says: "Each sporangium shows a transverse, or somewhat oblique annulus, just as in that genus [Gleichenia]; though some authors have denied that the apparent annulus is really distinct from the rest of the sporangial wall, the inspection of the specimens, especially those of $O$. robustior Stur, leaves no doubt that the former interpretation is correct."

Briefly, to sum up the arguments for the presence of the Gleicheniacer in the Paleozoic, it may be admitted that the dichotomous branching can not be taken as proof positive of Gleicheniaceous affinity, but with the fruiting characters the question seems to be on a slightly better plane. That the fruit in Otigocarpia is disposed in a circular sorus composed of from 6 to 10 pyriform sporangia, there can not be doubt, but whether they have, or have not, an annulus is perhaps not definitely settled: If the annulus is indisputably present, this genus should apparently be regarded as closely allied to, if not, indeed, belonging to, the Gleicheniaceæ, while the absence of the complete annulus would refer it to the Marattiaceæ. We may conclude with Seward, ${ }^{2}$ who says: "We find in Carboniferous types undoubted indications of anatomical and other features which in succeeding ages became the marks of Gleicheniaceæ."

The presence of the Gleicheniaceæ in the Triassic and Jurassic is attested at a number of points, though not all the forms so considered by their authors can always be accepted. Thus, Fontaine's genus Mertensides, from the Upper Triassic of Virginia, is now generally accepted as being Marattiaceous; it lacks the characteristic forking of Gleichenia, but has the 4 to 6 sporangia arranged in a circular sorus. From the Upper Triassic of Basel Leuthardt ${ }^{3}$ has described a species as Gleichenites gracilis, which shows the sori composed of 5 sporangia, each sporangium with a horizontal annulus, and Schenk has figured a species as Gleichenites microphyllus from the Rhaetic of Franconia, but no fruiting organs have been found for it.

In the Jurassic the forms referred to the Gleicheniaceæ become increasingly evident, though relatively few have the sporangia preserved. So many of these have the small rounded pinnules and the dichotomous habit of branching so very like the Gleichenias that there can be little or no doubt as to the correctness of their reference to this family.

In the Cretaceous the Gleicheniaceæ were evidently well established and widely distributed, for in the Wealden we find them present in England, Belgium, North Germany, and other localities, while in the

1 Studies in Fossil Botany, ed. 2, vol. 1, 1908, p. 290.

2 Fossil Plants, vol. 2, 1910, p. 351.

3 Die Keuperflora von Neuewelt bei Basel, Abh. Schweiz. Pal. Ges., vol. 31, 1904, p. 40, pl. 18 ,fig. 3. 
United States remains so described are known from the Kootenai, Dakota, Raritan, and in the Montana. From the Kome (Urogonian) of Greenland Heer has described many beautifully preserved examples, a few of which show the characteristic sporangia.

In the course of investigations by the United States Geological Survey into the coal resources of the West that have been going on for the past six or eight years, many beautifully preserved ferns have been found, among them a considerable number that clearly belong to Gleichenia. ${ }^{1}$ The specimens here considered may be known as:

GLEICHENIA PULCHELLA, new species.

Plate 44, figs. 1, 2.

Frond probably of large size, distinctly xerophilous in habit; primary leaf axis unknown; secondary axis stiff, naked, terete and smooth, dichotomous, or pseudo-dichotomous, the included bud large, always (?) undeveloped; internodes apparently equal, each with about three or four pairs of alternate, scattered pinnules; terminal branches (pinnæ) apparently equal, erect, stiff, each with numerous pairs of mainly alternate, rather remote, sessile, linear--lanceolate pinnules; pinnules with a larger basal segment, thence cut nearly to the midrib into numerous round moniliform lobes, these being reduced until near the tip they are merely undulations; margins clearly revolute; midrib relatively thick, 3-striate; nervation of segments obscure but apparently not forked, delicate; fruit-dots (?) immature, minute, usually about two to each segment.

Type.-Cat. No. 34,446, U.S.N.M. (pl. 44, fig. 2); para-type, Cat. No. 34447, U.S.N.M. (pl. 44, fig. 1).

Locality.-One-half mile north of mine D, Superior, Wyoming (sec. 17, T. 21 N., R. 102 W.).

Geological horizon.-Cretaceous (Montana). Rock Springs coal group, Mesaverde formation.

This species is represented by a large number of examples, the two figured being in some respects perhaps the best. Judging by analogy with living species, it probably bore fronds of large size, for which supposition there is some warrant in larger fragments of what appear to have been axes lower than the ones shown in the figures. The lowest segment of the axis, or internode, figured is nearly $2 \mathrm{~mm}$. thick and is preserved for a length of $2.5 \mathrm{~cm}$. The internodes are 3 to $4 \mathrm{~cm}$. long, apparently nearly or quite equal, and, as stated above, bear 3 or 4

\footnotetext{
1 The generic name Gleichenites, established by Göppert in 1836 for certain Paleozoic ferns, is not tenable for Mesozoic or later fossil forms. The type species of Gleichenites is G. linkii, but this, according to the opinion of David White, is a Sphenopteris of the group represented by S. hoeninghausi Brongniart, 1828, which is the frond of the best known of the Pteridosperms, Lyginodendron(Lygenopteris). The other four species originally placed in the genus by Göppert are now distributed among Sphenopteris, Neuropteris, and Eremopteris, and the name Gleichenites is abandoned for Paleozoic ferns. On the principle of "once a synonym always a synonym," it can not be resurrected for subsequent use.
} 
pairs of alternate remote pinnules. The terminal leafy branches (pinnæ) exceeded $6 \mathrm{~cm}$. in length. The pinnules range in length from about 1 to $2.5 \mathrm{~cm}$.; their width is between 2 and $3 \mathrm{~mm}$. The pinnules were clearly coriaceous in texture, as they appear thick and rigid, and have the margins distinctly revolute.

The presence of sori in these specimens is more or less in doubt, there being only a number of minute dots or pits, usually about two in each segment, that may represent very immature fruit. Their relation to the veins can not be certainly ascertained.

The living representatives of the Gleicheniaceæ, upward of 100 in number, according to American students, are comprised in four genera, two of which (Platyzoma and Stromatopteris) are monotypic. The other species are distributed among Gleichenia proper and Dicranopteris, the latter covering the ground of the former section Mertensia. ${ }^{1}$ These are distinguished mainly as follows: In Dicranopteris the veins are free, once or several times forked, and the sori dorsal on the veins, while in Glechenia the veins are simple and the sori terminal on the veins. According to Underwood, ${ }^{2}$ followed by Maxon, ${ }^{3}$ who has recently monographed the American forms, the genus Gleichenia as now restricted is not found in the New World, all being referable to Dicranopteris. It is believed that the fossil form under consideration, belongs, so far as the essential features can be made out, to Gleichenia. If this is correct, and it is thought to be, it is of interest as showing that in the late Cretaceous time the genus Gleichenia was an inhabitant of America, and many hundreds of miles north of the present habitat of any living representative of the family.

In many cases the absence of fructification in fossil ferns makes their classification more or less a matter of question, but with the present specimens there can hardly be the possibility of error. The manner of forking, the included terminal bud and the coriaceous, narrow, moniliform pinnules with revolute margins, are so exactly the characters of Gleichenia that there can be no reasonable question. It is, for instance, very much like the Australian $G$. circinata Swartz, which is itself apparently a variable species.

Among fossil species referred to Gleichenia the present one is perhaps closest to several described by Heer ${ }^{4}$ from the Kome (Lower Cretaceous) of Greenland. It has the same habit as G. zippei Heer, but is much smaller. It is nearest to $G$. gracilis Heer and to $G$. delicatula Heer, but differs in regard to the lobation and shape of the pinnules.

1 Mertensia is preoccupied by the Boraginaceous genus of this name.

${ }^{2}$ Bull. Torr. Bot. Club, vol. 34, 1907, pp. 243-262.

3 North Amer. Flora, vol. 16, pt. 1, 1909, pp. 53-63.

4 Flora Foss. Arct., vol. 3 (Kreide-flora d. Arct. zone), 1874, pls. 3-11. 


\section{$2 \mathrm{BHL}$ Biodiversity Heritage Library}

Knowlton, Frank Hall. 1913. "Description of a new fossil fern of the genus Gleichenia from the Upper Cretaceous of Wyoming." Proceedings of the United States National Museum 45(1994), 555-558. https://doi.org/10.5479/si.00963801.45-1994.555.

View This Item Online: https://www.biodiversitylibrary.org/item/31799

DOI: https://doi.org/10.5479/si.00963801.45-1994.555

Permalink: https://www.biodiversitylibrary.org/partpdf/24712

\section{Holding Institution}

Smithsonian Libraries

\section{Sponsored by}

Smithsonian

\section{Copyright \& Reuse}

Copyright Status: NOT_IN_COPYRIGHT

This document was created from content at the Biodiversity Heritage Library, the world's largest open access digital library for biodiversity literature and archives. Visit BHL at https://www.biodiversitylibrary.org. 